\title{
Middle East Respiratory Syndrome - Corona Virus (MERS- CoV): A Deadly Killer
}

\author{
Harshit A. Jadav \\ L.J.Institute of Pharmacy, Ahmedabad
}

\begin{abstract}
Middle east respiratory syndrome-corona virus , a new species of corona virus has emerge in the middle east countries and has very high (almost 50\%) fatality ratio. There is no any specific symptoms which are seen in the MERS-CoV. The symptoms which are seen are similar to those of simple general respiratory disease. There is no any treatment as well as no any vaccine available for the condition. Only one thing which are in our hand is to prevent the disease. Transmission of the disease is mainly by person to person transmission or by the virus affected bat or camels which are seen in the most of the cases. Disease is mostly seen in aged people (age >65) which has week immune system and which are under ICU or Dialysis are more prone to the disease. Phylogenetic analysis shows that the patients which have the disease they have directly or indirectly contact shows that person to person transmission occur in the MERS-CoV. The pathogenesis of the disease is still unknown. Clusters of cases in Saudi Arabia, Jordan, the UK, France, Tunisia, and Italy are being investigated. The genome sequence of the virus has identified and real time reverse transcriptase polymerase chain reaction(real time -RT-PCR) has important diagnostic tool for the identification of the disease. The WHO and CDC are currently working on the specific transmission pattern and finding the new scope of treatment and vaccine. There are specific prevention information for the patients, hospital staff, and visitors and the person who travels in the middle east countries guided by $W H O$ and $C D C$.
\end{abstract}

Key-words: MERS-CoV, beta-coronavirus, Middle East Respiratory Syndrome, novel coronavirus, London1_novel CoV

\section{Introduction about Coronavirus:}

Coronaviruses are species in the genera of virus belonging to the subfamily Coronavirinae in the family Coronaviridae. Coronaviruses are enveloped viruses with a positive-sense RNA genome and with a nucleocapsid of helical symmetry. The genomic size of coronaviruses ranges from approximately 26 to 32 kilobases, extraordinarily large for an RNA virus. With its characteristic surface, the virions appear as a crown like image under the electron microscope and so the viruses are named after the Latin wordcorona, meaning 'crown' or 'halo'.In people, coronaviruses can cause illnesses ranging in severity from the common cold to Severe Acute Respiratory Syndrome (SARS). . In people, coronaviruses can cause illnesses ranging in severity from the common cold to Severe Acute Respiratory Syndrome (SARS). First Human CoVs isolated in the 2060s. The human coronaviruses mainly infect the upper respiratory and gastrointestinal tract. They often result in upper respiratory tract infections (simple colds) in humans, causing mild illnesses usually of short lasting nature with a rhinitis, cough, sore throat, as well as fever.

Six human CoVs (HCoVs) have been identified to date:

1. $\mathrm{HCoV}-220 \mathrm{E}$

2. $\mathrm{HCoV}-\mathrm{OC} 43$

3. HCoV-NL63

4. HCoV-HKU1

5. SARS-CoV

6. Middle East Respiratory Syndrome Coronavirus (MERS-CoV)

Different types of Corona Virus:

Alpha Co-V:

- Human examples: HCoV-220E, HCoV-NL63

- Pig, dog, and cat CoVs

Beta Co-V:

- HCoV-OC43, HCoV-HKU1, HCoV-SARS

- MHV, rat, pig and cow CoVs

- MERS-CoV

Gamma Co-V:

- Chicken and turkey CoVs

Delta Co-V:

- Bird CoVs 


\section{Middle East Respiratory Syndrome Coronavirus (MERS-CoV):}

Middle East Respiratory Syndrome (MERS) is a viral respiratory illness. MERS is caused by a corona virus called "Middle East Respiratory Syndrome Corona virus" (MERS-CoV). MERS-CoV is a beta corona virus. It was first reported in September 2012 in Saudi Arabia. MERS-CoV used to be called "novel corona virus". Corona viruses are a large family of viruses that cause illness in humans and animals

The novel corona virus, first detected in septmber2012.It was named by the Corona virus Study Group of the International Committee on Taxonomy of Viruses in May 2013. Nine countries have now reported cases of human infection with MERS-CoV. Death has occurred in about half of cases

\section{Taxonomy of virus:}

MERS-CoV is more closely related to the bat coronaviruses HKU4 and HKU5 (lineage 2C) than it is to SARS-CoV sharing more than $90 \%$ sequence identity with their closest relationships, bat coronaviruses HKU4 and HKU5 and therefore considered to belong to the same species by the International Committee on Taxonomy of Viruses (ICTV).

\section{Other names:}

- novel coronavirus ( $\mathrm{nCoV})$

- London1_novel CoV 2012(34)

- Human Coronavirus-Erasmus Medical Center (HCoV-EMC)

\begin{tabular}{|l|l|}
\hline Virus & ssRNA, positive single strand RNA virus \\
\hline Order & Nidovirales \\
\hline Family & Coronaviridae \\
\hline Subfamily & Coronavirinae \\
\hline Genus & Betacoronavirus \\
\hline Species & Human coronavirus HKU1 \\
& Rousettus bat coronavirus HKU9 \\
& Murine coronavirus \\
& Severe acute respiratory syndrome-related coronavirus (SARS-Co- \\
& V) \\
& Middle East respiratory syndrome- MERS-CoV \\
\hline
\end{tabular}

\section{Structural features of novel MERS-CoV:} (Credit: NIAID))

(Electron microscope image of MIddle East Respiratory Syndrome virus particles, colorized in yellow.

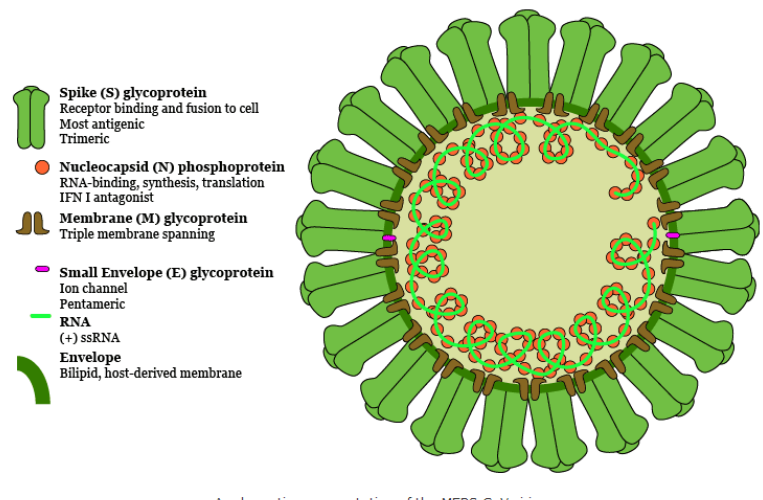

Here the virus of MERS-CoV contains mainly spike like structures mainly consists of glycoproyein for mainly receptor binding and antigenic activity. It also contains neucleocapsid phosphoprotein for RNA-binding, Membrane glycoprotein for triple membrane spanning, and positive strand RNA (+)ssRNA. The glycoprotein spike serves as the shape of crown for the virus so called as corona virus.

\section{Histroy of MERS-CoV:}

Dr. Zaki isolated and identified a previously unknown coronavirus from the lungs of a 60 -year-old Saudi Arabian man with pneumonia and acute renal failure. ${ }^{[2][3]}$ He used a broad-spectrum "pan-coronavirus" RT-PCR method and got a positive result. The UK Health Protection Agency (HPA) confirmed the diagnosis of severe respiratory illness associated with a new type of coronavirus in a second patient, a 49-year-old Qatari man who had recently been flown into the UK. He died from an acute, serious respiratory illness in a London hospital. ${ }^{[4][5]}$. In September 2012 Ron Fouchier speculated that the virus might have originated in bats. ${ }^{[6]}$. In September 2012, the United Kingdom's Health Protection Agency (HPA) named it the London1 novel CoV 2012 and produced the virus' preliminary phylogenetic tree, the genetic sequence of the virus ${ }^{[12]}$ based on the 
virus's RNA obtained from the Qatari case. ${ }^{[5][7]}$ On 25 September 2012, the World Health Organization(WHO) announced that it is "engaged in further characterizing the novel coronavirus" and that it has "immediately alerted all its Member States about the virus and has been leading the coordination and providing guidance to health authorities and technical health agencies." ${ }^{[8]}$ In May 2013, the Coronavirus Study Group of the International Committee on Taxonomy of Viruses adopted the official designation, the Middle East Respiratory Syndrome Coronavirus (MERS-CoV), ${ }^{[1]}$ which was adopted by the World Health Organization to "provide uniformity and facilitate communication about the disease." ${ }^{[9]}$. Fouchier and his team of researchers successfully sequenced the whole genome of the new coronavirus naming the viral strain Human CoronavirusErasmus Medical Center (hCoV-EMC) after their research center. They published its genomic sequence in the GenBank(accession code: JX869059) in the fall of 2012. ${ }^{[5]}$

\section{Natural reservoir:}

In September 2012, Ron Fouchier speculated that the virus might have an animal origin originating in bats. ${ }^{[10],[11]}$ Sequencing and subsequent analysis indicated that the novel coronavirus shared high sequence homology with both bat ${ }^{[5]}$. On July 21, 2013, the World Organisation for Animal Health (OIE) announced that "currently there is no strong evidence to suggest that camels are a source of infection for human cases of MERS." ${ }^{[13]}$ Several victims have been known to have had contact with camels, including visibly ill camels, however. ${ }^{[14]}$ On 9 August, 2013 a report in the Lancet showed that 50 of 50 (100\%) blood serum from Omani camels and 11 of $105(14 \%)$ from Spanish camels had protein-specific antibodies against MERS-CoV spike. Countries like Saudi Arabia and the United Arab Emirates produce and consume large amounts of camel meat and there's a possibility that African or Australian bats harbor the virus which then camels carried to the Middle East. ${ }^{[11]}$

\section{Emergens of MERS-CoV:}

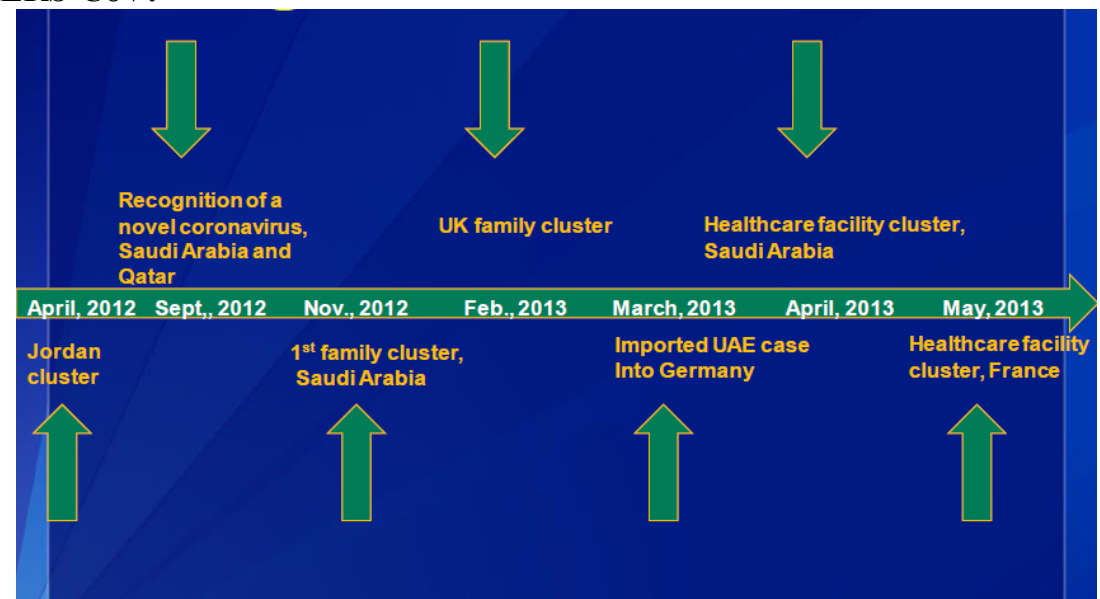

\section{Clinical definations and reporting criteria:}

\begin{tabular}{|c|c|c|}
\hline Clinical definition & & Epidemiological criteria \\
\hline $\begin{array}{l}\text { A person with acute respiratory syndrome } \\
\text { which may include fever }\left(\geq 38^{\circ} \mathrm{C}, 100.4^{\circ} \mathrm{F}\right) \text { and } \\
\text { cough } \\
-\quad \text { requiring hospitalization } \\
\text { OR } \\
\text { - with suspicion of lower airway } \\
\text { involvement (clinical or radiological } \\
\text { evidence of consolidation) } \\
\text { not explained by any other infection or } \\
\text { any other aetiology }\end{array}$ & AND & $\begin{array}{l}\text { One or more of the followings within the last } 14 \\
\text { days before onset of illness } \\
\text { - close contact* with a confirmed or probable } \\
\text { case of Middle East Respiratory Syndrome while } \\
\text { the case was ill } \\
\text { OR } \\
\text { - residence in or history of travel to the Arabian } \\
\text { Peninsula or neighboring countries** }\end{array}$ \\
\hline \multicolumn{3}{|c|}{$\begin{array}{l}\text { Probable case } \\
\text { A person fitting the clinical definition AND epidemiological criteria either above but no possibility of } \\
\text { laboratory confirmation either because the patient or samples are not available or there is no testing } \\
\text { available for other respiratory infections }\end{array}$} \\
\hline \multicolumn{3}{|c|}{$\begin{array}{c}\text { Confirmed case } \\
\text { A person with laboratory confirmation of infection with the MERS coronavirus. }\end{array}$} \\
\hline Close c & & \\
\hline
\end{tabular}

[https://ceno.chp.gov.hk/casedef/casedef.pdf] ${ }^{[20]}$ 
Diagnosis:

confirmatory real-time RT-PCR assays exist for rapid identification of MERS-CoV from patientderived samples (suchThroat-swab (Eurotubo, Deltalab), sputum, tracheal-aspirate, or bronchoalveolar-lavage), upE (targets elements upstream of the E gene) and 1A (targets the ORF1a gene) ${ }^{[15]}$.

In addition, hemi-nested sequencing amplicons targeting RdRp (present in all corona viruses) and $\mathrm{N}$ gene (specific to MERS-CoV) fragments can be generated for confirmation via sequencing. Reports of potential polymorphisms in the $\mathrm{N}$ gene between isolates highlight the necessity for sequence-based characterization. Protocols for biologically safe immune fluorescence assays (IFA) have also been developed.

[(A)Bilateral enhanced pulmonary hilar vascular shadows (more prominent on the left) and accentuated bronchovascular lung markings. Multiple patchy opacities in middle and lower lung fields, On admission (B) Opacities more confluent and dense, 2 days later] [Zaki et al. N Engl J Med 2012 367:1814-20]

\section{Progression of disease:}

The disease is started with initially simple respiratory problem with simple fever, chills, muscle ache and shortness of breath. Then it leads to severe pneumonia within 2 to 3 days. Then after some period of time it will convert in to the SARS (severe acute respiratory syndrome) or ARDS (acute respiratory distress syndrome). Then death is occurred in almost half of the cases ${ }^{[1]}$

\section{MERS-CoV cases and death:}

\begin{tabular}{|l|l|}
\hline Countries & Cases (death) \\
\hline France & $2(1)$ \\
\hline Italy & $1(0)$ \\
\hline Jordan & $2(2)$ \\
\hline Qatar & $6(3)$ \\
\hline Saudi Arabia & $115(49)$ \\
\hline Tunisia & $3(1)$ \\
\hline United kingdom (UK) & $3(2)$ \\
\hline United Arab Emirates (UAE) & $6(2)$ \\
\hline Total & $139(60)$ \\
\hline
\end{tabular}

\section{Symptoms of middle east respiratory syndrome(MERS-CoV):}

Fever, chills, muscle ache, \& shortness of breath are seen in most of the patients with coronavirus. Some patients also had gastrointestinal symptoms which leads to sometimes diarrhea and vomiting and nausea .kidney impairment is seen in about half of the cases ${ }^{[1]}$. MERS-CoV is known to infect cell lines of the intestinal tract. MERS-CoV hasno any specific symptoms, it generally shows all the symptoms which are occurred in the pneumonia and other respiratory disease. So its difficult to understand the disease with respect to the symptoms.

Phylogenetic analysis of middle east respiratory syndrome:
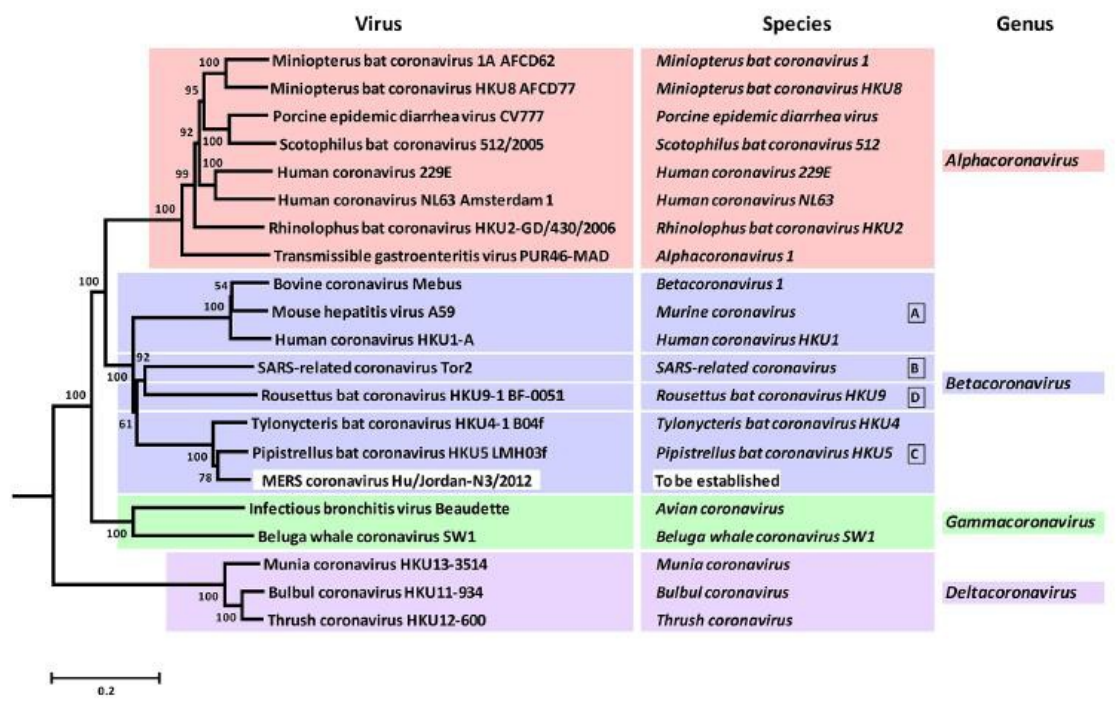

[de Groot et al. J Virol. May, 2013; 
Testing algorithm for the middle east respiratory syndrome:

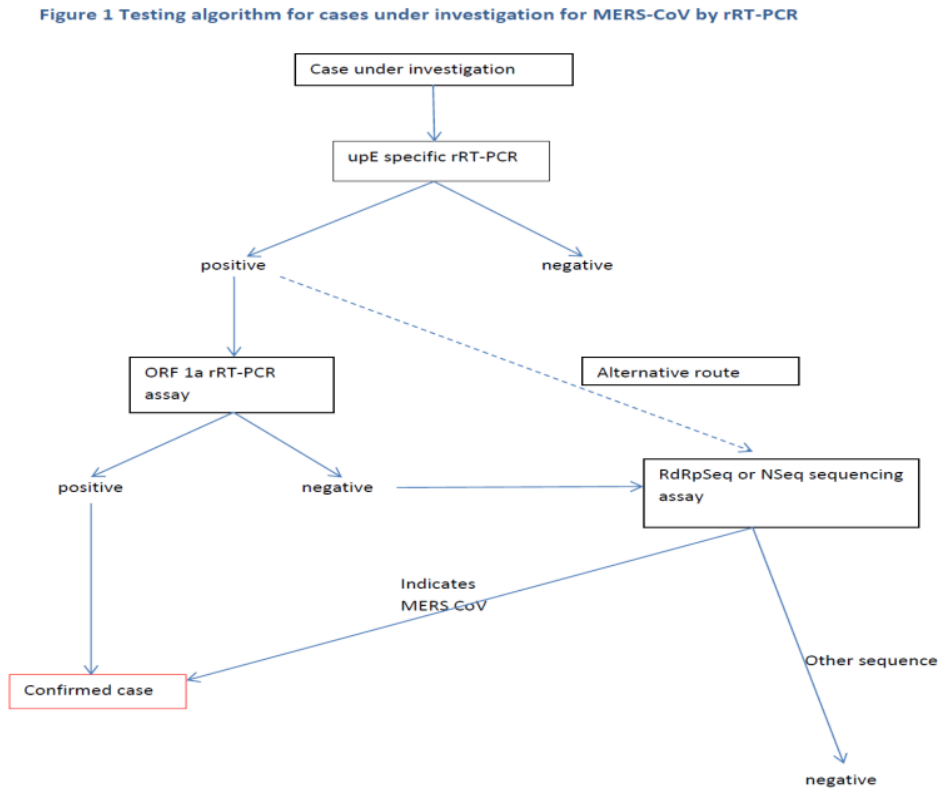

Table 1 Specimens suitable for testing for MERS-CoV based on current evidence

\begin{tabular}{|l|l|l|l|}
\hline Specimen type & $\begin{array}{l}\text { Transport } \\
\text { medium }\end{array}$ & $\begin{array}{l}\text { Transport to } \\
\text { laboratory }\end{array}$ & $\begin{array}{l}\text { Dangerous goods } \\
\text { shipping category }\end{array}$ \\
\hline Sputum & no & $\begin{array}{l}4^{\circ} \mathrm{C}^{*} \\
\text { If a delay in testing of > } \\
48 \text { hours consider } \\
\text { freezing and shipping } \\
\text { with dry ice }\end{array}$ & $\begin{array}{l}\text { Biological substance, } \\
\text { Category B }\end{array}$ \\
\hline Bronchoalveolar lavage & no & as for sputum & as above \\
\hline Tracheal aspirate & no & as for sputum & as above \\
\hline Nasopharyngeal aspirate & no & as for sputum & as above \\
\hline $\begin{array}{l}\text { Combined } \\
\text { nasopharyngeal/oropharyngeal } \\
\text { swabs }\end{array}$ & $\begin{array}{l}\text { virus } \\
\text { transport } \\
\text { medium }\end{array}$ & as for sputum & as above \\
\hline $\begin{array}{l}\text { Tissue from biopsy or autopsy } \\
\text { including lung }\end{array}$ & $\begin{array}{l}\text { virus } \\
\text { transport } \\
\text { medium or } \\
\text { sterile } \\
\text { saline if } \\
\text { specimen } \\
\text { is also for } \\
\text { bacterial } \\
\text { culture }\end{array}$ & as for sputum & as above \\
\hline $\begin{array}{l}\text { Serum for serological testing: } \\
\text { paired samples are preferable with } \\
\text { the initial sample collected in the } \\
\text { first week of illness and the second } \\
\text { collected two to three weeks later. } \\
\text { A single serum sample should be } \\
\text { collected at least } 14 \text { days after } \\
\text { onset of symptoms }\end{array}$ & no & $\begin{array}{l}4^{\circ} \mathrm{C}^{*} \text { or frozen and } \\
\text { shipped on dry ice }\end{array}$ & as above \\
\hline
\end{tabular}

Time line for UK Cluster of MERS-CoV:

[HPA UK Novel Coronavirus Investigation Team; Eurosurv 2013; 18(11)]

Evidence of person-to-person transmission was to be found out in this study. Coinfection with influenza (index case) and parainfluenza type 2 (both secondary cases) are repoterd. No sustained chains of transmission are measured. And Incubation periodwas found out to be 1-9 days. ${ }^{[17]}$

\section{Transmission:}

We still do not know the answer to this question. It is unlikely that transmission of the MERs-CoV to people occurs through direct exposure to an infected camel, as very few of the cases have reported a camel exposure.MERS-CoV has been shown to spread between people who are in close contact. ${ }^{[1]}$ Transmission from infected patients to healthcare personnel has also been observed. Clusters of cases in Saudi Arabia, Jordan, the UK, France, Tunisia, and Italy are being investigated. 
Infection control measures: ${ }^{[20]}$

Specimens Collection

$>$ Exercise standard, contact, droplet and airborne precautions for patients under isolation.

Transport of patients

$>$ Patient should wear a surgical mask and attendants should practice standard, contact, droplet and airborne precautions.

Linen and Laundry

$>$ Pack on site and avoid shaking and Send to laundry as soon as possible.

Waste Management

$>$ All wastes arising from the patient care should be considered as clinical waste using the red bags.

$>$ Staff removing wastes should wear appropriate PPEs.

Administration Support

$>$ Management should ensure adequate resources, issue formal instructions for visitors and patients, and postappropriate signage.

\section{A special prevention for persons who travels in Arabian and neighbouring country:}

CDC does not recommend that travelers change their plans because of MERS. However, the Saudi Arabia Ministry of Health has made special recommendations for travelers to Hajj and Umrah. ${ }^{[20]}$ Because of the risk of MERS, Saudi Arabia recommends that the following groups should postpone their plans for Hajj and Umrah this year:

- People over 65 years old

- Children under 12 years old

- Pregnant women

- People with chronic diseases (such as heart disease, kidney disease, diabetes, or respiratory disease)

- People with weakened immune systems

- People with cancer or terminal illnesses

CDC encourages people traveling to Saudi Arabia to perform Hajj or Umrah to consider this advice. People who are concerned about MERS should discuss their travel plans with their doctor.

\section{Treatment \& Vaccine:}

There are no specific treatments recommended for illnesses caused by MERS-CoV. Medical care is supportive and to help relieve symptoms. Only symptomatic treatment is given to the patients according to its severity ${ }^{[18]}$ There is no any vaccine available for this particular disease. CDC currently working and discussing with partners the possibility of developing one.

\section{Prevention for individual:}

There are specific precaution which are acquired for the prevention and protection of the Disease. ${ }^{[16][18][20]}$

- Avoid to going into the hospital where the chances of getting infection is very high.

- Wash your hands often with soap and water for 20 seconds, and help young children do the same. If soap and water are not available, use an alcohol-based hand sanitizer.

- Cover your nose and mouth with a tissue when you cough or sneeze then throw the tissue in the trash.

- Avoid touching your eyes, nose, and mouth with unwashed hands.

- Avoid close contact, such as kissing, sharing cups, or sharing eating utensils, with sick people.

- Clean and disinfect frequently touched surfaces, such as toys and doorknobs. Wash your hands before and after visiting someone in a care home (many hospitals provide antibacterial gel in wards).

\section{Prevention for hospital staff:}

- Hospital staff that comes into contact with patients should maintain very high standards of hygiene and take extra care when treating patients with pneumonia and MERS-CoV.

- Staff should thoroughly wash and dry their hands before and after caring for a patient, before and after touching any potentially contaminated patients

- Patients with a known or suspected MERS-CoV infection should be isolated.

- The hospital environment, including floors, toilets and beds, should be kept as clean and dry as possible. 


\section{Prevention for visitor to the patients:}

- Visitors can reduce the chance of spreading MRSA to other people by not sitting on the patient's bed and by cleaning their hands before and after entering the ward.

- They should use hand wipes or hand gel before touching the person they are visiting.

Patients who travels to the Arabian countries:

Taking these everyday actions can help prevent the spread of germs and protect against colds, flu, and other illnesses: ${ }^{[18]}$

- Wash your hands often with soap and water. If soap and water are not available, use an alcohol-based hand sanitizer

- Avoid touching your eyes, nose, and mouth. Germs spread this way.

- Avoid close contact with sick people.

- Be sure you are up-to-date with all of your shots, and if possible, see your healthcare provider at least 4-6 weeks before travel to get any additional shots.

- If you are sick:

- Cover your mouth with a tissue when you cough or sneeze, and throw the tissue in the trash.

- Avoid contact with other people to keep from infecting them.

\section{Clinical information about the MERS-CoV:}

Health care providers should be alert to patients who develop severe acute lower respiratory illness (e.g., requiring hospitalization) within 14 days after traveling from countries in the Arabian or neighbouring countries, excluding those who transited at airports without entering the countries.[20][20]

Consider other more common causes of respiratory illness, such as influenza.

- Immediately report patients with unexplained respiratory illness and who meet CDC's criteria for "patient under investigation (PUI)" to CDC through the state or local health department. A PUI is a person with -

$\circ$ an acute respiratory infection, which may include fever $\left(\geq 38^{\circ} \mathrm{C}, 100.4^{\circ} \mathrm{F}\right)$ and cough;

- suspicion of pulmonary parenchyma disease (e.g., pneumonia or acute respiratory distress syndrome based on clinical or radiologic evidence of consolidation);

- history of travel from countries in the Arabian Peninsula* or neighbouring countries* within 14 days;

- not already explained by any other infection or etiology, including all clinically indicated tests for community-acquired pneumonia according to local management guidelines.

- Collect specimens for MERS-CoV testing from all PUIs.

Recent findings of virus antibodies in camels:

The recent study by Reusken and colleagues (link to the article) suggests that MERS-CoV or a virus very similar to the MERS-CoV has been recently circulating among camels. ${ }^{[10]}$ The most critical question remains to be answered, that is, the type of human exposures that result in infection. Most human cases do not have a history of direct contact with camels; if camels or other animals are the source, the route of transmission to humans may be indirect. Although related viruses infect bats, molecular clock analyses have been unable to identify direct ancestors of MERS-CoV. ${ }^{[12]}$ Anecdotal exposure histories suggest that patients had been in contact with dromedary camels or goats.

\section{Question unsolved???}

1) Pathophysiology of the MERS-CoV is still unknown.

2) Treatment and vaccine development of the disease is the primary requirement.

3) What are actual mode of transmission of the disease.?

4) Where the actual origin of the MERS-CoV.?

5) What are the actual causes of the disease?

These are some question which are still unanswered for the community. WHO and CDC are currently working on these topic to finding out the solution of the MER-CoV. Yet there is no any further information is available for the disease, we can only prevent the disease not cure. So finally MERS$\mathrm{CoV}$ is deadly kiler now a days. 


\section{Reference:}

[1]. Abdullah A et al, "hospital outbreak of Middle east respiratory syndrome", The new England journal of medicine ,August 1, 2013;365:407-415

[2]. Falco, Miriam (24 September 2012). "New SARS-like virus poses medical mystery". CNN. Retrieved 27 September 2012. http://thechart.blogs.cnn.com/2012/09/24/new-sars-like-virus-poses-medical-mystery

[3]. Dziadosz, Alexander (13 May 2013). "The doctor who discovered a new SARS-like virus says it will probably trigger an epidemic at some point, but not necessarily in its current form.". Reuters. Retrieved 25 May 2013. http://www.reuters.com/article/2013/05/13/us-coronavirus-egypt-idUSBRE94C0MH20130513

[4]. "New Coronavirus Has Many Potential Hosts, Could Pass from Animals to Humans Repeatedly". Sciencedaily. Retrieved 13,December 2012. http://www.sciencedaily.com/releases/2012/12/120201083200.htm

[5]. Novel coronavirus infection - update (Middle East respiratory syndrome- coronavirus) (Report). World Health Organization. May 2013. http://www.who.int/csr/don/2013 0523 ncov/en/index.html

[6]. Doucleef, Michaeleen (26 September 2012)."Scientists Go Deep On Genes Of SARS-Like Virus". Associated Press. Retrieved 27 September 2012 http://www.npr.org/blogs/health/2012/09/25/151670135/scientists-go-deep-on-genes-of-sars-like-virus

[7]. Guery, B.; Poissy, J.; El Mansouf, L.; Séjourné, C.; Ettahar, N.; Lemaire, X.; Vuotto, F.; Goffard, A.; Behillil, S.; Enouf, V.; Caro, V.; Mailles, A.; Che, D.; Manuguerra, J. C.; Mathieu, D.; Fontanet, A.; van der Werf, S. (2013). "Clinical features and viral diagnosis of two cases of infection with Middle East Respiratory Syndrome coronavirus: a report of nosocomial transmission". Lancet (Elsevier Ltd): [cited $2013 \quad$ may 13] Available http://www.thelancet.com/journals/lancet/article/PIIS0140-6736(13)60982-4/fulltext

[8]. "Novel coronavirus update-new virus to be called MERS-CoV". World Health Organization. 15 May2013.http://www.euro.who.int/en/health-topics/emergencies/international-health-regulations/news/news/2013/05/novelcoronavirus-update-new-virus-to-be-called-mers-cov

[9]. Cell Host Response to Infection with Novel Human Coronavirus EMC Predicts Potential Antivirals and Important Differences with SARS Coronavirus (Report). American Society for Microbiology. [cited 2013 April 30]; Available from: http://mbio.asm.org/content/4/3/e00155-13.full

[10]. Doucleff, Michaeleen "Holy Bat Virus! Genome Hints At Origin Of SARS-Like Virus". NPR. Retrieved 29 September 2012. http://www.npr.org/blogs/health/2012/09/28/151844734/holy-bat-virus-genome-hints-at-origin-of-sars-like-virus

[11]. Lu, Guangwen; Liu, Di (2012). "SARS-like virus in the Middle East: A truly bat-related coronavirus causing human diseases". Protein \& Cell 3 (11): 803-805. http://link.springer.com/article/10.1007\%2Fs13238-012-2811-1

[12]. Donald G. McNeil Jr (September) "Camels Linked to Spread of Fatal Virus", The New York Times http://www.nytimes.com/2013/09/12/health/camels-linked-to-spread-of-fatal-virus.html

[13]. Reusken, C. B. E. M.; Haagmans, B. L.; Müller, M. A.; Gutierrez, C.; Godeke, G. J.; Meyer, B.; Muth, D.; Raj, V. S.; Smits-De Vries, L.; Corman, V. M.; Drexler, J. F.; Smits, S. L.; El Tahir, Y. E.; De Sousa, R.; van Beek, J.; Nowotny, N.; van Maanen, K.; Hidalgo-Hermoso, E.; Bosch, B. J.; Rottier, P.; Osterhaus, A.; Gortázar-Schmidt, C.; Drosten, C.; Koopmans, M. P. G. (2013). "Middle East respiratory syndrome coronavirus neutralising serum antibodies in dromedary camels: a comparative serological study". Lancet (Elsevier Ltd). [cited 2013 Aug 9]; Available from: http://www.thelancet.com/journals/laninf/article/PIIS1473-3099(13)70154-6/fulltext

[14]. Roos, Robert UK agency picks name for new coronavirus isolate (Report). University of Minnesota, Minneapolis, MN: Center for Infectious Disease Research \& Policy (CIDRAP).[cited 2012 Sep 25]; Available from: http://www.cidrap.umn.edu/newsperspective/2012/09/uk-agency-picks-name-new-coronavirus-isolate

[15]. Interim guidance document Clinical management of severe acute respiratory infections when novel coronavirus is suspected: What to do and what not to do. Geneva, World Health Organization, 2013. http://www.who.int/csr/disease/coronavirus infections/InterimGuidance ClinicalManagement NovelCoronavirus 11Feb13u.pdf

[16]. Rapid risk assessment, severe respiratory disease associated with corona virus European Centre for Disease Prevention and Control, Stockholm, 2012 http://www.eurosurveillance.org/images/dynamic/EE/V14N23/V14N23.pdf

[17]. N van Doremalen, T Bushmaker, V J Munster Stability of middle east respiratory syndrome coronavirus (mers-cov) under different environmental conditions, eurosurveillance, 2013;18:1-4

[18]. European centre for disease and prevention control , coronavirus infection. http://www.ecdc.europa.eu/EN/HEALTHTOPICS/CORONAVIRUS-INF ECTIONS/Pages/index.aspx

[19]. World health organization, global alert and response (GAR). http://www.who.int/csr/disease/coronavirus infections/en/index.html

[20]. Communicable Disease Surveillance ,Case Definitions Surveillance and Epidemiology Branch, Centre for Health Protection, Department of Health, Hong Kong Special Administrative Region, People's Republic of China Version 8.11 , 201314 June, https://ceno.chp.gov.hk/casedef/casedef.pdf 